\title{
Quality of 'Cripps Pink' apples stored under controlled atmosphere with ultra-low and extremely low oxygen partial pressures or treated with 1-methylcyclopropene
}

\author{
Raquel Carlos Fernandes ${ }^{1, \star}(\mathbb{D})$, Cristiano André Steffens ${ }^{1}$ (D), Jéssica Mayumi Anami ${ }^{1}$ (D), Deysi Jhoana \\ Camayo Mosquera² (D), Cassandro Vidal Talamini do Amarante ${ }^{1}$ (D) Auri Brackmann ${ }^{3}$ (D) \\ 1. Universidade do Estado de Santa Catarina - Departamento de Agronomia - Lages (SC), Brazil. \\ 2. Universidad Nacional de Colombia - Departamento de Ciencias Agrícolas - Palmira, Colombia. \\ 3. Universidade Federal de Santa Maria - Departamento de Fitotecnia - Santa Maria (RS), Brazil. \\ Received: Apr. 15, 2021 | Accepted: Sep. 13, 2021 \\ Section Editor: Gabriel Constantino Blain \\ *Corresponding author: raaquel-carlos@hotmail.com \\ How to cite: Fernandes, R. C., Steffens, C. A., Anami, J. M., Mosquera, D. J. C., Amarante, C. V. T. and Brackmann, A. (2021). Quality \\ of 'Cripps Pink' apples stored under controlled atmosphere with ultra-low and extremely low oxygen partial pressures or treated with \\ 1-methylcyclopropene. Bragantia, 80, e5921. https://doi.org/10.1590/1678-4499.2021115
}

\begin{abstract}
The objective of this work was to evaluate the effects of low, ultra-low, and extremely low partial pressures of $\mathrm{O}_{2}$ in a controlled atmosphere (CA) and 1-methylcyclopropene (1-MCP) on the postharvest quality of 'Cripps Pink' apples. The treatments used were $21.00 \mathrm{kPa}$ of $\mathrm{O}_{2}$ (cold storage [CS]), CS +1-MCP, and CA conditions with $2.00,1.00,0.60$ and $0.25 \mathrm{kPa}$ of $\mathrm{O}_{2}$, without 1-MCP. All fruit were stored at $1.5 \pm 0.2^{\circ} \mathrm{C}$, relative humidity $(\mathrm{RH}) 92 \pm 2 \%$, and partial pressure of $\mathrm{CO}_{2}<0.5 \mathrm{kPa}$, for 4.5 and 8 months, followed by another seven days of shelf life $\left(20 \pm 2{ }^{\circ} \mathrm{C} / \mathrm{RH}\right.$ of $\left.60 \pm 5 \%\right)$. Respiration and ethylene production rates were reduced in all CA conditions and the CS + 1-MCP treatment when compared to the CS without 1-MCP, in both storage periods. The application of 1-MCP delayed ripening and reduced the quality loss of the fruits stored for 4.5 months. The $\mathrm{CA}$ with 0.6 and $0.25 \mathrm{kPa}$ of $\mathrm{O}_{2}$ reduced the incidence of superficial scald, decay, mealiness, and skin greasiness, and maintained the background color of the epidermis of the fruits in storage for 8 months. Among the CA conditions, the treatment of $0.25 \mathrm{kPa}$ presented the highest production of ethanol and acetaldehyde in the fruits stored for 8 months. Treatment of $0.6 \mathrm{kPa}$ of $\mathrm{O}_{2}$ kept higher values of total phenolic compounds, in the peel and flesh, in both storage periods. Fruits stored under $0.6 \mathrm{kPa}$ of $\mathrm{O}_{2}$ showed the best quality after 8 months of storage.
\end{abstract}

Key words: Malus domestica (Borkh), ethylene, physiological disorders, fruticulture, postharvest.

\section{INTRODUCTION}

The fruit ripening process involves many physiological changes that can influence the sensory quality of apples like changes in the contents of phenolic compounds and antioxidant capacity of the fruit. Apples are a valuable source of bioactive compounds (Mditshwa et al. 2018) and the loss of these functional characteristics during postharvest may occur because of the conditions to which the fruits are subjected during storage (Stanger et al. 2018). Currently, the technologies most used for maintaining the postharvest quality of apples, in addition to refrigeration, are the treatment with 1-methylcyclopropene (1-MCP) and storage under a controlled atmosphere (CA).

The 1-MCP has shown positive effects in maintaining the quality of different apple cultivars during storage (Watkins 2006). This compound reduced ethylene production in 'Pink Lady' apple clones (Cripps Pink and Rosy Glow cultivars) (Thewes et al. 2018; Williamson et al. 2018), moreover, this growth regulator may not be efficient in maintaining the quality of 'Cripps Pink' apples in long-term storage (Williamson et al. 2018).

Static CA, with low (1.2 to $2 \mathrm{kPa})$, ultra-low $(0.7 \mathrm{kPa}$ to $1.2 \mathrm{kPa})$, and extremely low $(<0.7 \mathrm{kPa}) \mathrm{O}_{2}$ partial pressures, and, more recently, dynamic $\mathrm{CA}$, where there are changes in $\mathrm{O}_{2}$ partial pressures throughout storage, show positive results 
on the delayed ripening of some apple cultivars (Berghetti et al. 2020; Mditshwa et al. 2018). However, if poorly handled, static CA, such as the use of $\mathrm{O}_{2}$ partial pressures lower than what is tolerable for a specific cultivar, can induce or aggravate physiological storage disturbances, as observed by Thewes et al. (2021), in Royal Gala apples. In higher $\mathrm{O}_{2}$ partial pressures (low and ultra-low), especially when combined with prolonged storage periods ( $\geq 4$ to 5 months), static CA may not be efficient in maintaining the quality of stored apples. For this reason, it is imperative to consider the behavior of a given cultivar under hypoxia conditions and storage time, which may be different between cultivars (Bodbodak and Moshfeghifar 2016).

'Pink Lady' apples ('Cripps Pink') showed good quality conservation in CA with $1.0 \mathrm{kPa} \mathrm{O}_{2}+<0.5$ and $1.0 \mathrm{kPa} \mathrm{CO}_{2}$ and $1.5 \mathrm{kPa} \mathrm{O}_{2}+1.0$ and $2.0 \mathrm{kPa} \mathrm{CO}_{2}$, at a temperature of $0.5^{\circ} \mathrm{C}$ (Brackmann et al. 2005). However, storage temperatures slightly higher $\left(1.2\right.$ to $\left.2{ }^{\circ} \mathrm{C}\right)$ than those normally used $\left(0.5\right.$ to $\left.1.0^{\circ} \mathrm{C}\right)$ show better quality maintenance for 'Gala' apples and lower energy consumption for fruit cooling when stored in extremely low $\mathrm{O}_{2}$ conditions (Mazzurana et al. 2016). Thus, 'Cripps Pink' apples can tolerate $\mathrm{O}_{2}$ partial pressures below $1 \mathrm{kPa}$ under storage temperature just above $0.5^{\circ} \mathrm{C}$. Additionally, storage at extremely low $\mathrm{O}_{2}$ partial pressures, such as under dynamic CA (DCA) conditions, monitored by the respiratory quotient $(\mathrm{RQ})$ or by chlorophyll fluorescence (CF) (DCA-RQ $=1.5$ with an average of $0.1 \mathrm{kPa} \mathrm{O}_{2}+1.2 \mathrm{kPa} \mathrm{CO}_{2}$ and DCA-CF with an average of $0.4 \mathrm{kPa} \mathrm{O}_{2}+1.2 \mathrm{kPa} \mathrm{CO}_{2}$ ), provided 'Galaxy' apples with a higher content of phenolic compounds and higher antioxidant activity (Stanger et al. 2018).

The objective of this work was to evaluate the effects of CA conditions with low, ultra-low, and extremely low $\mathrm{O}_{2}$ partial pressures and treatment with 1-MCP in cold storage on the quality of 'Cripps Pink' apples stored for 4.5 and 8 months.

\section{MATERIAL AND METHODS}

The experiment was carried out using 'Cripps Pink' apples harvested in a commercial orchard located in the municipality

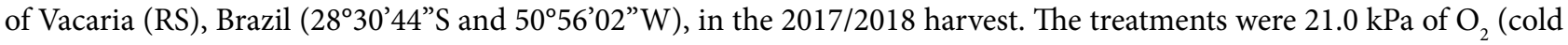
storage; CS), CS + 1-MCP $\left(1.0 \mu \mathrm{L} \cdot \mathrm{L}^{-1}\right)$, and CA conditions with $\mathrm{O}_{2}$ partial pressures of $2.00,1.00,0.60$, and $0.25 \mathrm{kPa}$. All the fruits were stored at $1.5 \pm 0.2^{\circ} \mathrm{C}, 92 \pm 2 \%$ relative humidity, and $\mathrm{CO}_{2}$ partial pressure $<0.5 \mathrm{kPa}$.

Each treatment was placed in an experimental mini chamber with a volume of $0.5 \mathrm{~m}^{3}$. The installation of the storage atmospheres for the CA treatments was done immediately after placing the fruits and closing the mini chambers. The $\mathrm{O}_{2}$ was initially reduced to $5 \mathrm{kPa}$ by injecting pure nitrogen $\left(\mathrm{N}_{2}\right)$ from high-pressure cylinders, with subsequent gradual reduction of oxygen to $2 \mathrm{kPa}$ until the seventh day of storage. For treatments with $\mathrm{O}_{2}$ partial pressures below $2 \mathrm{kPa}$, the pressure was gradually reduced to $1.00 \mathrm{kPa}$ from the seventh to the 14th day of storage. The pressure of the treatments with $\mathrm{O}_{2}$ partial pressures below $1.00 \mathrm{kPa}$ were progressively reduced to $0.60 \mathrm{kPa}$ from day 14 to 21 of storage. From the 21 st day of storage, the treatment with $0.25 \mathrm{kPa}$ of $\mathrm{O}_{2}$ had $\mathrm{O}_{2}$ gradually reduced to the pre-established pressure until the 28 th day of storage. Hydrated lime sachets $\left[\mathrm{Ca}(\mathrm{OH})_{2}\right](1 \mathrm{~kg}$ of hydrated lime per $20 \mathrm{~kg}$ of apple) were added to all mini chambers to absorb the $\mathrm{CO}_{2}$ released by the fruit respiration. The atmospheres were monitored daily using an electronic gas analyzer (Schele, Germany), and $\mathrm{O}_{2}$ partial pressures were corrected when necessary, injecting pure nitrogen $\left(\mathrm{N}_{2}\right)$ to reduce $\mathrm{O}_{2}$, or injecting atmospheric air to increase $\mathrm{O}_{2}$.

The SmartFresh product (0.14\% of 1-MCP in the powder formulation) was used for the application of $1-\mathrm{MCP}\left(1.0 \mu \mathrm{L} \cdot \mathrm{L}^{-1}\right)$. The amount of 1-MCP used was calculated according to the total volume of $0.5 \mathrm{~m}^{3}$ of the experimental mini-chamber where it was applied. The product was wetting with distilled water for its consequent volatilization. The fruits remained exposed to the treatment for $24 \mathrm{~h}$ at ambient temperature $\left(20 \pm 2^{\circ} \mathrm{C}\right)$.

At harvest, the fruits were evaluated for peel color, flesh firmness, soluble solids (SS), and titratable acidity (TA). After 4.5 and 8 months of storage, at the chamber opening, the fruits were evaluated for respiration rates and ethylene production, background color of the epidermis, the incidence of scalding and decay, and greasiness index at the time of storage. After another 7 days of shelf life, in addition to the variables mentioned above, flesh browning, mealiness, SS, TA, fermentative metabolism compounds (acetaldehyde, ethanol, and ethyl acetate), total phenolic compounds (TPC), and total antioxidant activity (TAA) were determined. Respiration and ethylene production rates, flesh firmness, TA, and SS were evaluated according to the methodology described by Thewes et al. (2015). The SS/TA ratio was calculated based on the SS and TA 
values. The incidence of flesh browning, mealiness, and decay, as well as the content of TPC and TAA, were evaluated according to the methodology described by Stanger et al. (2018). The TAA of the flesh was assessed using the 1.1-diphenyl2-picrylhydrazyl radicals (DPPH method), and in the peel by the 2.2'-azinobis (3-ethylbenzothiazoline-6-sulphonic acid) radicals (ABTS method). Floegel et al. (2011) suggest that the ABTS test shows better results than the DPPH test when assessing tissues rich in pigments, and would be more indicated in such situations, such as apple peel, for example.

The greasiness index was assessed according to the methodology described by Yang et al. (2017a). The fermentative metabolism compounds were quantified as described by Anami et al. (2020). The scald incidence (\%) was visually assessed by counting the fruits with dark spots on the surface. The background color of the epidermis was evaluated using a Minolta colorimeter, model CR 400, measuring the hue angle $\left(\mathrm{h}^{\circ}\right)$ in the equatorial and less red region of the fruit.

The experiment was conducted in a factorial scheme with six storage conditions vs. two storage periods. Each treatment consisted of four replicates, and the experimental unit consisted of 24 fruits. The data were submitted to analysis of variance (ANOVA), and the treatment means were compared using the LSD test $(\mathrm{p}<0.05)$. Percentage data were, prior to ANOVA, transformed to sine $\operatorname{arc}[(\mathrm{x}+0.1) / 100]^{0.5}$.

\section{RESULTS AND DISCUSSION}

At the time of harvest, 'Cripps Pink' apples showed $\mathrm{h}^{\circ}$ values of 35.7 and 107.0, respectively, in the redder and less red region of the epidermis, flesh firmness of $82.3 \mathrm{~N}$, TA of $0.51 \%$ malic acid, and SS of $13.8^{\circ} \mathrm{Brix}$.

Ethylene production was reduced in all treatments, when compared to the control, in both storage periods (Table 1). After 4.5 months of storage, the lowest rate of ethylene production was observed in the fruits of the CS + 1-MCP and CA treatments with $\mathrm{O}_{2} \leq 1.0 \mathrm{kPa}$. However, after 8 months of storage, the lowest rate of ethylene production was observed in fruits stored in $\mathrm{CA}$ with $\mathrm{O}_{2} \leq 1.0 \mathrm{kPa}$. The increase in ethylene production in fruits treated with 1-MCP with the advance of the storage period was also observed in 'Rosy Glow' apples after 4.5 months under CS, suggesting that the fruits resumed the autocatalytic production of ethylene (Williamson et al. 2018). The reduction in ethylene production under CA is a result of the inhibition of the enzymes 1-aminocyclopropane-1-carboxylate (ACC) synthase and ACC oxidase due to the low $\mathrm{O}_{2}$ partial pressure (Saquet and Streif 2017). The effect of CA on the reduction of ethylene synthesis becomes more evident with longer storage, obtaining better results than the use of 1-MCP. In 'Cripps Pink' apples, there were also no differences between CA with ultra-low $\mathrm{O}_{2}\left(1.0 \mathrm{kPa} \mathrm{O}_{2}+1 \mathrm{kPa} \mathrm{CO}_{2}\right)$ and DCA, under extremely low $\mathrm{O}_{2}$ conditions $(0.29$ to $0.42 \mathrm{kPa}$ $\mathrm{O}_{2}+0.5 \mathrm{kPa} \mathrm{CO}_{2}$ ), during the 7 days of shelf life (Klein et al. 2020). However, unlike the 'Cripps Pink', the CA conditions with extremely low $\mathrm{O}_{2}\left(0.25 \mathrm{kPaO}_{2}+0.0 \mathrm{kPaCO}_{2} ; 0.4 \mathrm{kPaO}_{2}+1.2 \mathrm{kPa} \mathrm{CO}_{2}\right.$; and $\left.0.5 \mathrm{kPa} \mathrm{O}_{2}+1.2 \mathrm{kPa} \mathrm{CO}_{2}\right)$ for 'Royal Gala' showed less ethylene production than fruits maintained in CA conditions with ultra-low $\mathrm{O}_{2}\left(0.7 \mathrm{kPa} \mathrm{O}_{2}+1.5 \mathrm{kPaCO}_{2}\right.$ and $1.0 \mathrm{kPa} \mathrm{O}_{2}+2.0 \mathrm{kPa} \mathrm{CO}_{2}$ ) (Berghetti et al. 2020). These differences are possibly because different cultivars present different responses to the same CA conditions (Bodbodak and Moshfeghifar 2016).

After 4.5 months of storage, the fruits treated with 1-MCP, both at the chamber opening and after 7 days of shelf life, presented a lower respiration rate than the fruits under CS without 1-MCP (Table 1). After 8 months of storage, fruits of the CS + 1-MCP treatments showed a lower respiration rate at the chamber opening, followed by those of the CA treatment with $0.6 \mathrm{kPa}$ of $\mathrm{O}_{2}$. After 8 months of storage and plus 7 days of shelf life, CS + 1-MCP and CA treatments showed lower respiration rates than the fruits of the $\mathrm{CS}$, regardless of the $\mathrm{O}_{2}$ partial pressure. The effect of 1-MCP on reducing the respiration rate in apples is also reported by other authors (Thewes et al. 2018). The decrease in fruit respiration can be explained by a possible inhibition of the enzyme cytochrome oxidase in the electron transport chain in the respiration process, caused by the low oxygen condition (Weber et al. 2013). Furthermore, respiration rates may have been influenced by the action of ethylene, since the reduction in respiration was accompanied by a decrease in ethylene production. Saquet and Streif (2017) also observed this same behavior in 'Jonagold' apple and 'Conference' pear.

The background color of the epidermis did not differ between fruits treated and untreated with 1-MCP in CS, at chamber opening, in both storage periods (Fig. 1a). The evaluated CA conditions, concerning the CS, maintained the green color of the 'Cripps Pink' apple peel in all evaluations. However, the effect was more prominent at $0.25 \mathrm{kPa} \mathrm{O}_{2}$, which did not differ 
from $0.6 \mathrm{kPaO}_{2}$, at the chamber opening and plus 7 days of shelf life, and did not differ from $1.0 \mathrm{kPa} \mathrm{O}_{2}$ after plus 7 days of shelf life, in both storage periods. Mditshwa et al. (2017) also found better maintenance of the color of apples stored under low $\mathrm{O}_{2}$ partial pressures. The degradation of chlorophylls by the action of the enzyme chlorophyllase is accelerated by the high rate of ethylene production and high $\mathrm{O}_{2}$ partial pressure during the storage period (Gwanpua et al. 2014).

Table 1. Production of ethylene ( $\left.\mathrm{pmol} \cdot \mathrm{C}_{2} \mathrm{H}_{4} \cdot \mathrm{kg}^{-1} \cdot \mathrm{s}^{-1}\right)$ and respiration rate $\left(\mathrm{nmol} \cdot \mathrm{CO}_{2} \cdot \mathrm{kg}^{-1} \cdot \mathrm{s}^{-1}\right)$ in 'Cripps Pink' apples stored under different conditions $\left(1.5 \pm 0.2^{\circ} \mathrm{C} / 92 \pm 2 \% \mathrm{RH}\right)$, after 4.5 and 8 months and plus seven days of shelf life $\left(20 \pm 2{ }^{\circ} \mathrm{C} / 60 \pm 5 \% \mathrm{RH}\right)$.

\begin{tabular}{|c|c|c|c|c|c|}
\hline \multirow{2}{*}{ Treatment } & \multicolumn{2}{|c|}{$\begin{array}{l}\text { Ethylene production rate } \\
\text { Chamber opening }\end{array}$} & \multicolumn{3}{|c|}{7 days at $20^{\circ} \mathrm{C}$} \\
\hline & 4.5 months & 8 months & 4.5 months & 8 months & Mean \\
\hline $\mathrm{CS}\left(21 \mathrm{kPa} \mathrm{O}_{2}\right)$ & $2392.8 \mathrm{aA}$ & 2144.3aA & 7339.6 & 7978.9 & 7659.3a \\
\hline $\mathrm{CS}+1-\mathrm{MCP}$ & $398.5 \mathrm{~dB}$ & $1366.2 \mathrm{bA}$ & 2512.2 & 5322.5 & $3917.4 \mathrm{e}$ \\
\hline $2.00 \mathrm{kPa} \mathrm{O}_{2}$ & $1454.8 \mathrm{bA}$ & $1608.2 \mathrm{bA}$ & 5111.9 & 7750.1 & $6430.9 b$ \\
\hline $1.00 \mathrm{kPa} \mathrm{O}_{2}$ & $685.2 \mathrm{cdA}$ & $586.6 \mathrm{cA}$ & 4413.3 & 6407.2 & $5410.2 c$ \\
\hline $0.60 \mathrm{kPa} \mathrm{O}_{2}$ & $676.4 \mathrm{cdA}$ & 797.1cA & 3785.2 & 4879.4 & 4332.3de \\
\hline $0.25 \mathrm{kPa} \mathrm{O}_{2}$ & $919.8 \mathrm{cA}$ & $460.8 \mathrm{cA}$ & 4428.8 & 5480.7 & 4954.7cd \\
\hline Mean & - & - & $4598.5 B$ & $6303.1 \mathrm{~A}$ & \\
\hline CV (\%) & & & & 16.2 & \\
\hline \multirow[t]{2}{*}{ Treatment } & \multicolumn{2}{|c|}{$\begin{array}{l}\text { Respiration rate } \\
\text { Chamber opening }\end{array}$} & \multicolumn{3}{|c|}{7 days at $20^{\circ} \mathrm{C}$} \\
\hline & 4.5 months & 8 months & 4.5 months & 8 months & Mean \\
\hline $\mathrm{CS}(21 \mathrm{kPa} \mathrm{O})_{2}$ & $44.8 \mathrm{aB}$ & 337.7aA & $99.3 \mathrm{aB}$ & 192.2aA & - \\
\hline $\mathrm{CS}+1-\mathrm{MCP}$ & $26.9 \mathrm{bB}$ & $234.5 \mathrm{dA}$ & $78.1 \mathrm{bB}$ & $123.7 \mathrm{bA}$ & - \\
\hline $2.00 \mathrm{kPaO}_{2}$ & $30.3 a b B$ & $277.5 \mathrm{bA}$ & $90.9 \mathrm{abB}$ & $119.1 \mathrm{bA}$ & - \\
\hline $1.00 \mathrm{kPaO}_{2}$ & 30.0abB & $277.0 \mathrm{bA}$ & 81.0abB & $119.2 \mathrm{bA}$ & - \\
\hline $0.60 \mathrm{kPa} \mathrm{O}_{2}$ & $31.6 a b B$ & $255.9 c A$ & 81.6abB & $117.9 \mathrm{bA}$ & - \\
\hline $0.25 \mathrm{kPaO}_{2}$ & 34.1abB & $278.7 \mathrm{bA}$ & $85.4 \mathrm{abB}$ & $120.7 \mathrm{bA}$ & - \\
\hline Mean & - & - & - & - & \\
\hline $\mathrm{CV}(\%)$ & \multicolumn{2}{|c|}{7.7} & \multicolumn{3}{|c|}{11.8} \\
\hline
\end{tabular}

Note. Means followed by the same letters, uppercase in the lines and lowercase in the columns, do not differ by the LSD test at $5 \%$ of probability.

(a)

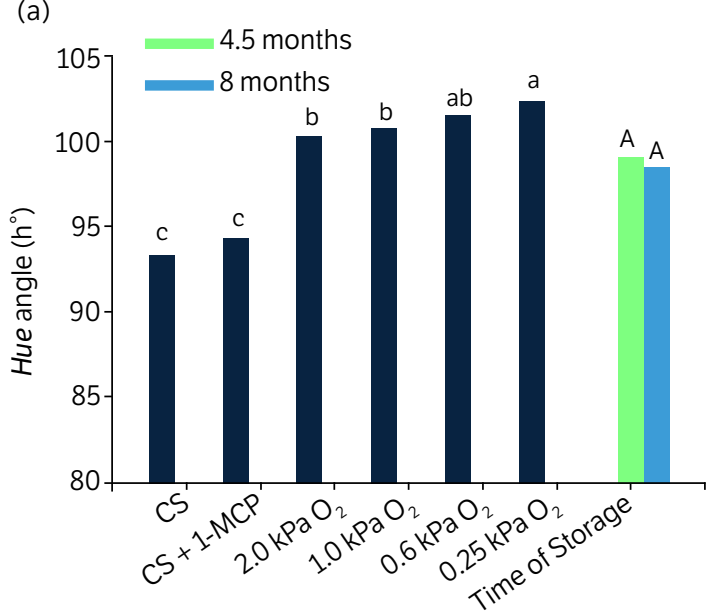

(b)

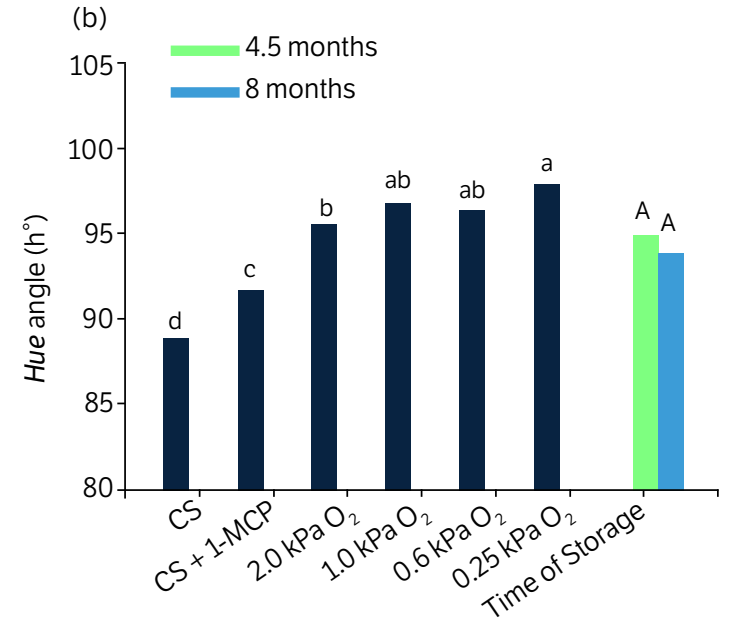

Figure 1. Hue angle $\left(\mathrm{h}^{\circ}\right)$ of the background color in 'Cripps Pink' apples stored under different storage conditions, after 4.5 and 8 months of storage $\left(1.5 \pm 0.2^{\circ} \mathrm{C} / 92 \pm 2 \% \mathrm{RH}\right)$, at the chamber opening (a) and plus 7 days of shelf life $\left(20 \pm 2{ }^{\circ} \mathrm{C} / 60 \pm 5 \% \mathrm{RH}\right)(\mathrm{b})$. Means followed by the same uppercase letter (time of storage) and same lowercase letter (storage conditions) in the bars do not differ by the LSD test at $5 \%$ of probability. 
Under CS, 1-MCP reduced greasiness when compared to those untreated, after 7 days of shelf life, in both storage periods (Fig. 2b). However, the lowest greasiness value was observed in storage under CA with $0.25,0.60$, and $1.00 \mathrm{kPa}$ of $\mathrm{O}_{2}$, in both moments of evaluation and storage periods. During storage, the greasy aspect is the result of a phase change of epicuticular waxes, from solid to liquid, due to the accumulation of more fluid constituents such as esters and short-chain alcohols (Yang et al. 2017b). Probably, these changes tend to intensify during storage, since the fruits stored for 8 months showed a higher greasiness incidence when compared to storage for 4.5 months. In 'Cripps Pink' apples, less greasiness was also observed in the epidermis associated with lower $\mathrm{O}_{2}$ partial pressure in storage (Klein et al. 2020). The authors attributed this effect to the fact that storage conditions using lower $\mathrm{O}_{2}$ partial pressures may induce an adaptation mechanism against hypoxia, causing the formation of 10-nonacosanol and octacosanol, which give the cuticle a crystalline structure.
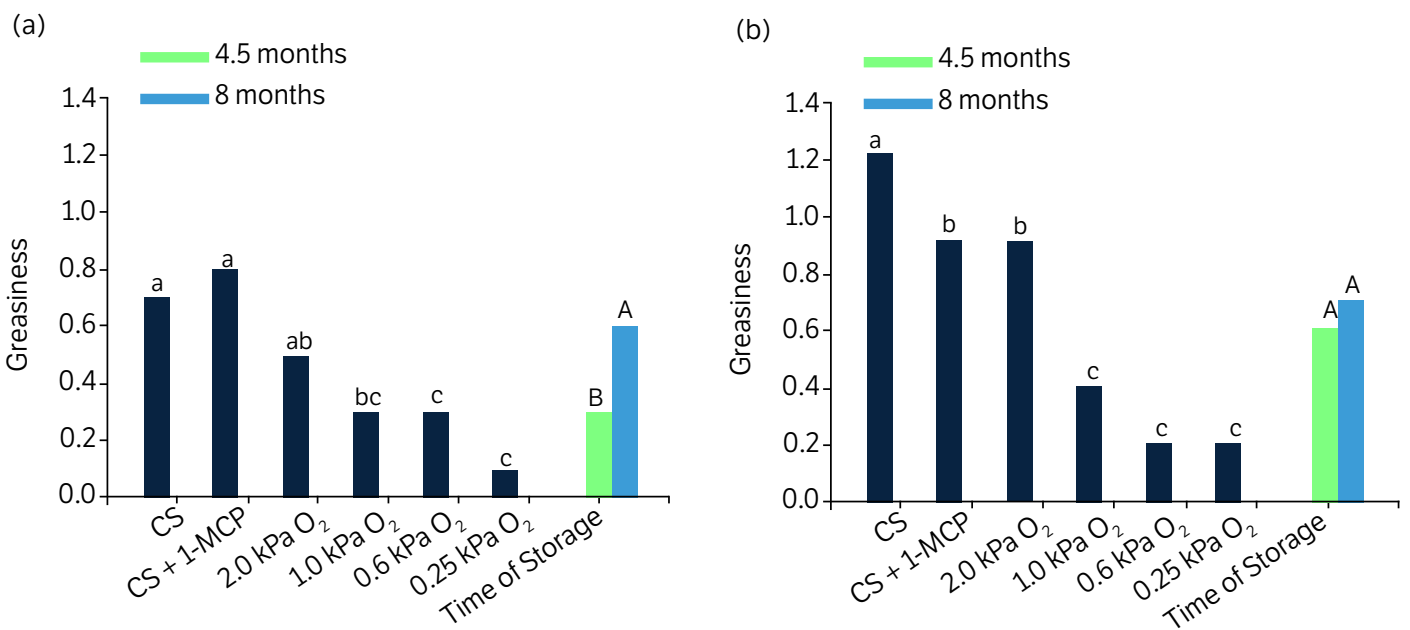

Figure 2. Greasiness of the epidermis of 'Cripps Pink' apples stored under different storage conditions, after 4.5 and 8 months of storage $\left(1.5 \pm 0.2^{\circ} \mathrm{C} / 92 \pm 2 \% \mathrm{RH}\right)$, at the chamber opening (a) and plus 7 days of shelf life $\left(20 \pm 2{ }^{\circ} \mathrm{C} / 60 \pm 5 \% \mathrm{RH}\right)(\mathrm{b})$.

Note. Means followed by the same uppercase letter (time of storage) and same lowercase letter (storage conditions) in the bars do not differ by the LSD test at $5 \%$ of probability. Greasiness scale: 0 = absence; 1 = light; 2 = moderate; 3 = high .

The conditions of 0.25 and $0.6 \mathrm{kPa}$ of $\mathrm{O}_{2}$ showed fruits with a higher SS value (5\%) than the fruits stored in CS without 1-MCP, but without differing from the fruits stored in the other conditions of CA and CS + 1-MCP, in both storage periods. The treatments with 1-MCP and storage under CA, regardless of the $\mathrm{O}_{2}$ partial pressure, showed fruits with higher TA compared to CS without 1-MCP, after 4.5 months of storage plus 7 days of shelf life (between 19 and $31 \%$ ). After 8 months of storage plus 7 days of shelf life, only fruits stored in CA with $0.6 \mathrm{kPa}$ of $\mathrm{O}_{2}$ showed a superior TA when compared to fruits under CS (11\%). All CA and 1-MCP conditions showed lower values of SS/TA ratio compared to CS (10\%), without differing from each other, regardless of the duration of the storage period (data not shown).

At 4.5 months of storage plus 7 days of shelf life, the effect of 1-MCP on the occurrence of mealiness was similar to CA, presenting lower values compared to fruits under CS without 1-MCP (Fig. 3a). The efficiency of 1-MCP in reducing mealiness has also been reported by Hackbarth et al. (2017), who studied 'Galaxy' apples stored under refrigeration. After 8 months of storage plus 7 days of shelf life, $\mathrm{CS}$ and CA with $2.0 \mathrm{kPa}$ of $\mathrm{O}_{2}$ showed higher values of mealiness incidence when compared to CA conditions with $0.25,0.60$, and $1.00 \mathrm{kPa}$ of $\mathrm{O}_{2}$. The treatments with 0.25 and $0.60 \mathrm{kPa}$ of $\mathrm{O}_{2}$ showed the lowest occurrences of mealiness, maintaining low values in both storage periods, showing the effects of reduced $\mathrm{O}_{2}$ partial pressures under CA for controlling this disorder, reducing post-storage quality losses. These results corroborate those obtained by Both et al. (2016), who studied 'Royal Gala' apples stored for 8 months under $\mathrm{CA}$ at the $\mathrm{O}_{2}$ partial pressure of $0.5 \mathrm{kPa}$, obtaining a lower occurrence of mealiness when compared to conditions of $0.7 \mathrm{kPa}$ of $\mathrm{O}_{2}$.

The application of 1-MCP did not influence the incidence of internal browning concerning untreated fruits (Fig. 3b). The $\mathrm{O}_{2}$ partial pressures of 0.25 and $0.6 \mathrm{kPa}$ provided a higher prevalence of internal browning than the fruits under CS 
but showed no significant difference from the fruits stored in $1.0 \mathrm{kPa}$ of $\mathrm{O}_{2}$ and $\mathrm{CS}+1$-MCP. Berghetti et al. (2020) also found a higher incidence of internal browning in 'Royal Gala' apples stored for 9 months under CA with partial pressures of $0.25 \mathrm{kPaO}_{2}+0.00 \mathrm{kPaCO}$ when compared to higher $\mathrm{O}_{2}$ and $\mathrm{CO}_{2}$ partial pressures $\left(0.7 \mathrm{kPa} \mathrm{O}_{2}+1.5 \mathrm{kPa} \mathrm{CO}_{2}\right.$ and $0.4 \mathrm{kPaO}_{2}+2.0 \mathrm{kPaCO}_{2}$ ) and observed a correlation between this disorder and higher concentrations of acetaldehyde and ethyl acetate. Between the storage periods, there was no difference for the evaluation of internal browning.
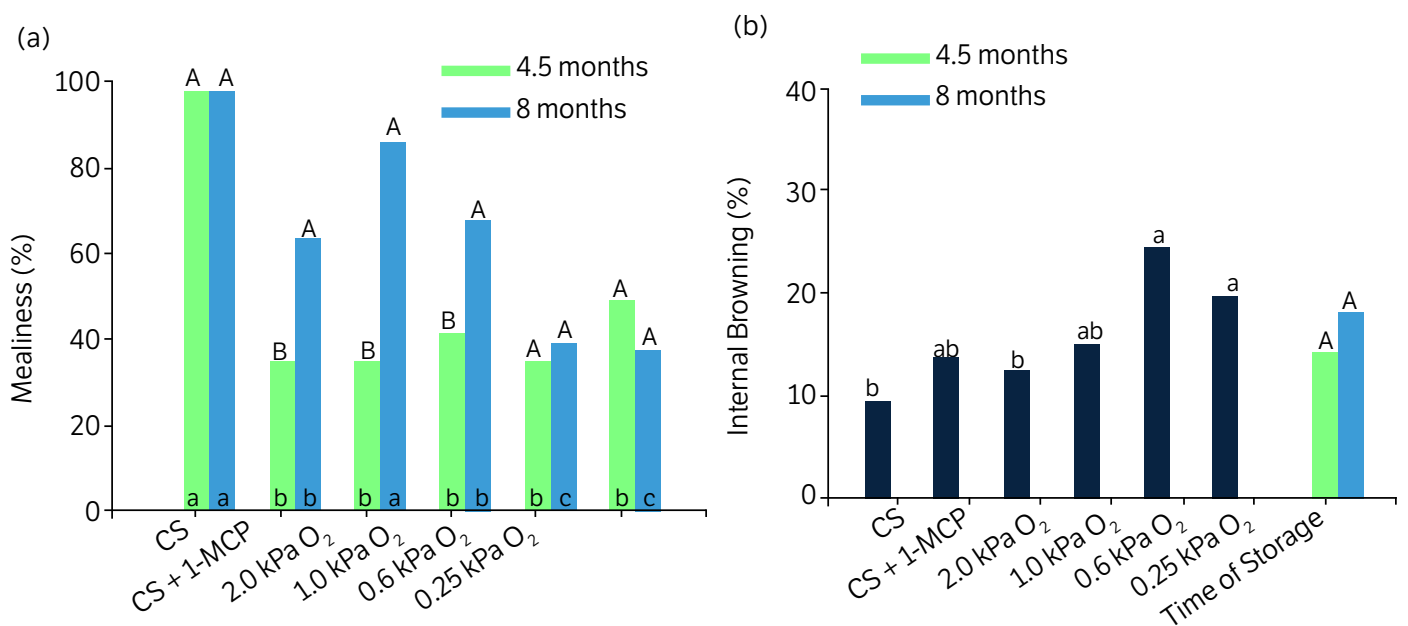

Figure 3. Incidence of the mealiness (a) and internal browning (b) of the 'Cripps Pink' apple flesh stored under different storage conditions after 4.5 and 8 months of storage $\left(1.5 \pm 0.2^{\circ} \mathrm{C} / 92 \pm 2 \% \mathrm{RH}\right)$ plus 7 days of shelf life $\left(20 \pm 2{ }^{\circ} \mathrm{C} / 60 \pm 5 \% \mathrm{RH}\right)$.

Note. Means followed by the same uppercase letter (time of storage) and same lowercase letter (storage conditions) in the bars do not differ by the LSD test at $5 \%$ of probability.

Fruits treated with 1-MCP under CS showed a reduction in the incidence of superficial scald when compared to untreated fruits in all evaluations performed (Table 2). The fruits stored under CA with 0.25 and $0.60 \mathrm{kPa}$ of $\mathrm{O}_{2}$ showed no symptoms of superficial scald. Prolonged storage (8 months) under CS + 1-MCP and CA with $2.00 \mathrm{kPa}$ of $\mathrm{O}_{2}$, at the chamber opening and plus 7 days of shelf life, and under CA with $1.00 \mathrm{kPa}$ of $\mathrm{O}_{2}$, after plus 7 days of shelf life, caused an increase in the incidence of superficial scald, while under CA with extremely low $\mathrm{O}_{2}\left(0.25 \mathrm{kPa}\right.$ and $0.60 \mathrm{kPa}$ of $\left.\mathrm{O}_{2}\right)$ the manifestation of the disorder was still inhibited. According to Mditshwa et al. (2017), the reduction of the $\mathrm{O}_{2}$ partial pressure during storage is an efficient method to control superficial scald, with a low accumulation of 6-methyl-5-hepten-2-one (MHO) in the fruits, which is related with the manifestation of superficial scald (Ding et al. 2019). The effect of reducing the $\mathrm{O}_{2}$ partial pressure in the control of superficial scald was observed in both storage periods.

Table 2. Incidence of superficial scald (\%) in 'Cripps Pink' apples stored under different conditions, after 4.5 and 8 months of storage $\left(1.5 \pm 0.2^{\circ} \mathrm{C} / 92 \pm 2 \% \mathrm{RH}\right)$ at the chamber opening and plus 7 days of shelf life $\left(20 \pm 2{ }^{\circ} \mathrm{C} / 60 \pm 5 \% \mathrm{RH}\right)$.

\begin{tabular}{|c|c|c|c|c|}
\hline \multirow{2}{*}{ Treatment } & \multicolumn{2}{|c|}{ Chamber opening } & \multicolumn{2}{|c|}{7 days } \\
\hline & 4.5 months & 8 months & 4.5 months & 8 months \\
\hline $\mathrm{CS}(21 \mathrm{kPa} \mathrm{O})$ & $37.3 a A$ & $44.8 \mathrm{aA}$ & 71.6aA & 83.5aA \\
\hline $\mathrm{CS}+1-\mathrm{MCP}$ & $0.0 \mathrm{bB}$ & $8.4 c A$ & $2.1 \mathrm{cA}$ & $8.1 \mathrm{dA}$ \\
\hline $2.00 \mathrm{kPaO}_{2}$ & $2.3 \mathrm{bB}$ & $24.0 \mathrm{bA}$ & $32.7 \mathrm{bB}$ & $61.5 \mathrm{bA}$ \\
\hline $1.00 \mathrm{kPaO}_{2}$ & $0.0 \mathrm{bA}$ & $1.1 \mathrm{dA}$ & $5.7 \mathrm{cB}$ & $41.7 \mathrm{cA}$ \\
\hline $0.60 \mathrm{kPa} \mathrm{O}$ & $0.0 \mathrm{bA}$ & $0.0 \mathrm{dA}$ & $0.0 \mathrm{cA}$ & $0.0 \mathrm{dA}$ \\
\hline $0.25 \mathrm{kPaO}_{2}$ & $0.0 \mathrm{bA}$ & $0.0 \mathrm{dA}$ & $0.0 \mathrm{cA}$ & $0.0 \mathrm{dA}$ \\
\hline Mean & - & - & - & - \\
\hline CV (\%) & 28.8 & 45.1 & & \\
\hline
\end{tabular}

Note. Means followed by the same letters, uppercase in the lines and lowercase in the columns, do not differ by the LSD test at $5 \%$ of probability. 
Regardless of the $\mathrm{O}_{2}$ partial pressure, storage under CA and the use of 1-MCP reduced the incidence of decay in both storage periods (Fig. 4). Brackmann et al. (2008) attribute the highest decay incidence in fruits under CS compared to CA to the most advanced stage of fruit ripening, making them susceptible to attack by pathogens, since the lower $\mathrm{O}_{2}$ pressures in the CA do not seem to interfere with the growth of fungi such as Penicillium expansum, common in post-harvest apples (Baert et al. 2007). Cold storage after 8 months showed a high decay incidence, showing that, in conditions of cold storage, the fruits should not be stored for long periods.
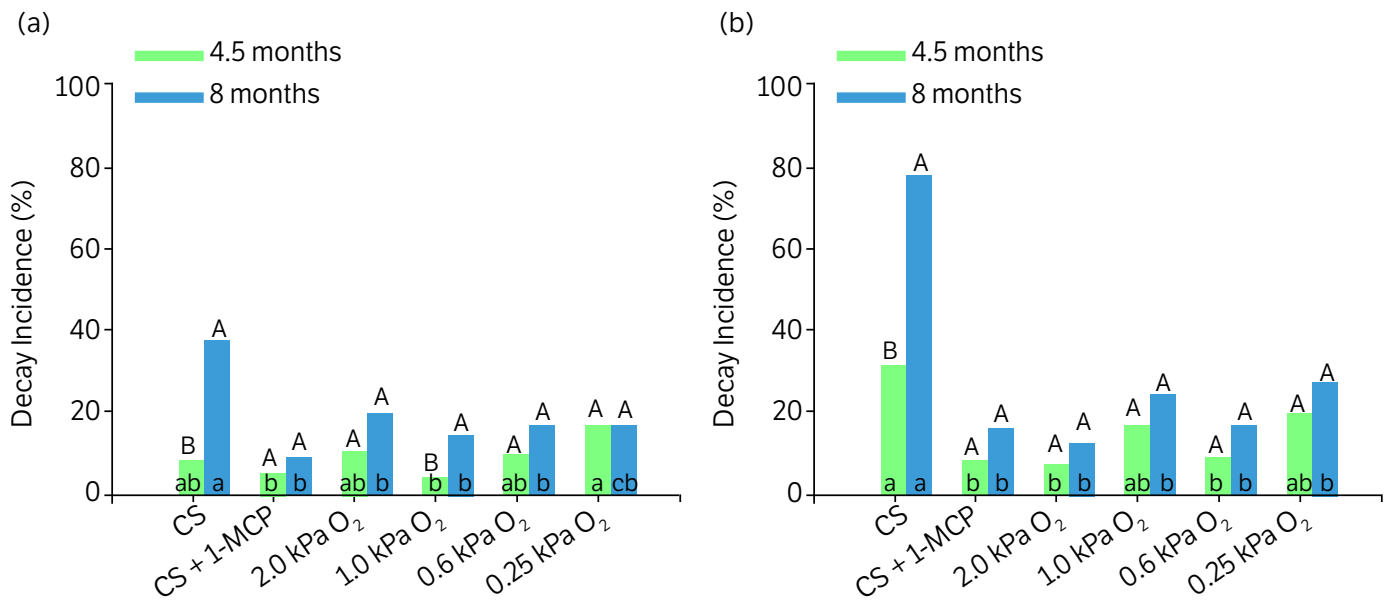

Figure 4. Decay incidence (\%) in 'Cripps Pink' apples stored under different conditions, after 4.5 and 8 months of storage $\left(1.5 \pm 0.2^{\circ} \mathrm{C} / 92 \pm 2 \% \mathrm{RH}\right)$ at the chamber opening (a) and plus 7 days of shelf life $\left(20 \pm 2^{\circ} \mathrm{C} / 60 \pm 5 \% \mathrm{RH}\right)(\mathrm{b})$.

Means followed by the same uppercase letter (time of storage) and same lowercase letter (storage conditions) in the bars do not differ by the LSD test at 5\% of probability.

Storage under CA with $0.25 \mathrm{kPa}$ of $\mathrm{O}_{2}$ and fruits under CS without 1-MCP showed the highest concentrations of acetaldehyde, ethanol, and ethyl acetate (Figs. 5a, b and c). Lower availability of $\mathrm{O}_{2}$ induces alternative routes to produce ATP, such as fermentation (Bailey-Serres et al. 2012), forming compounds that, in high concentrations, resulting in offflavors (Forney 2016). Fruits stored under $\mathrm{CA}$ with $\mathrm{O}_{2}$ partial pressures $\geq 0.60 \mathrm{kPa}$ showed lower ethanol and acetaldehyde values than fruits under CA with $0.25 \mathrm{kPa} \mathrm{O}_{2}$ and CS. According to Thewes et al. (2021), low oxygen storage is strongly related to a higher production of acetaldehyde and ethanol, in addition to increasing the incidence of internal browning when stored for a long period, as found in the present research. Ethanol production in apples under hypoxic conditions ( 0.40 and $0.80 \mathrm{kPa}$ of $\mathrm{O}_{2}$ ) may show a spike in production over time with a subsequent decrease until it is equal to the fruits under CS (Cukrov et al. 2016). Boeckx et al. (2019) reported the same behavior in 'Jonagold' apples under CA. According to the authors, the fruits may have activated other alternative pathways, such as alanine metabolism, since carbon losses through the fermentative route were inefficient for obtaining energy. Different apple cultivars under stress conditions, such as reduced $\mathrm{O}_{2}$ in storage, can use different strategies to achieve energy (Brizzolara et al. 2017).

The higher concentration of fermentative metabolism by products of fruits stored under CS without 1-MCP may be related to the advanced stage of ripening of the fruits of this treatment, which were probably in senescence. This statement can be supported by the high incidence of mealiness and reduced TA, already at 4.5 months of storage, as well as high yellowing of the epidermis (reduced $\mathrm{h}^{\circ}$ values) of these fruits. Fruits treated with 1-MCP under CS showed lower values of ethanol, acetaldehyde, and ethyl acetate than fruits under CS. A lower production of the compounds of the fermentative metabolism due to the application of 1-MCP in CS has also been reported by Huan et al. (2020), suggesting a probable reduction in the enzymatic activities of pyruvate decarboxylase and alcohol dehydrogenase, which controls anaerobic metabolism.

In general, the flesh and peel of 'Cripps Pink' apples showed higher TPC values when in more extended storage (Figs. 6a and b). However, CA conditions provided higher levels of TPC in the peel than under CS, in both storage periods, with emphasis on conditions with extremely low $\mathrm{O}_{2}$ partial pressures $(0.25$ and $0.6 \mathrm{kPa})$, after 8 months of storage plus 
7 days under of shelf life. The highest values of TPC in the flesh were obtained from fruits stored at $0.25 \mathrm{kPa}$ of $\mathrm{O}_{2}$. The storage of 'Galaxy' apples at extremely low $\mathrm{O}_{2}$ partial pressures resulted in a higher amount of TPC in the fruits, probably due to the stress induced by hypoxia (Stanger et al. 2018). According to Pedreschi and Lurie (2015), abiotic stress during postharvest, such as changes in atmospheric gases and temperatures, can induce changes in enzymatic activities and bioactive compounds in different vegetables.
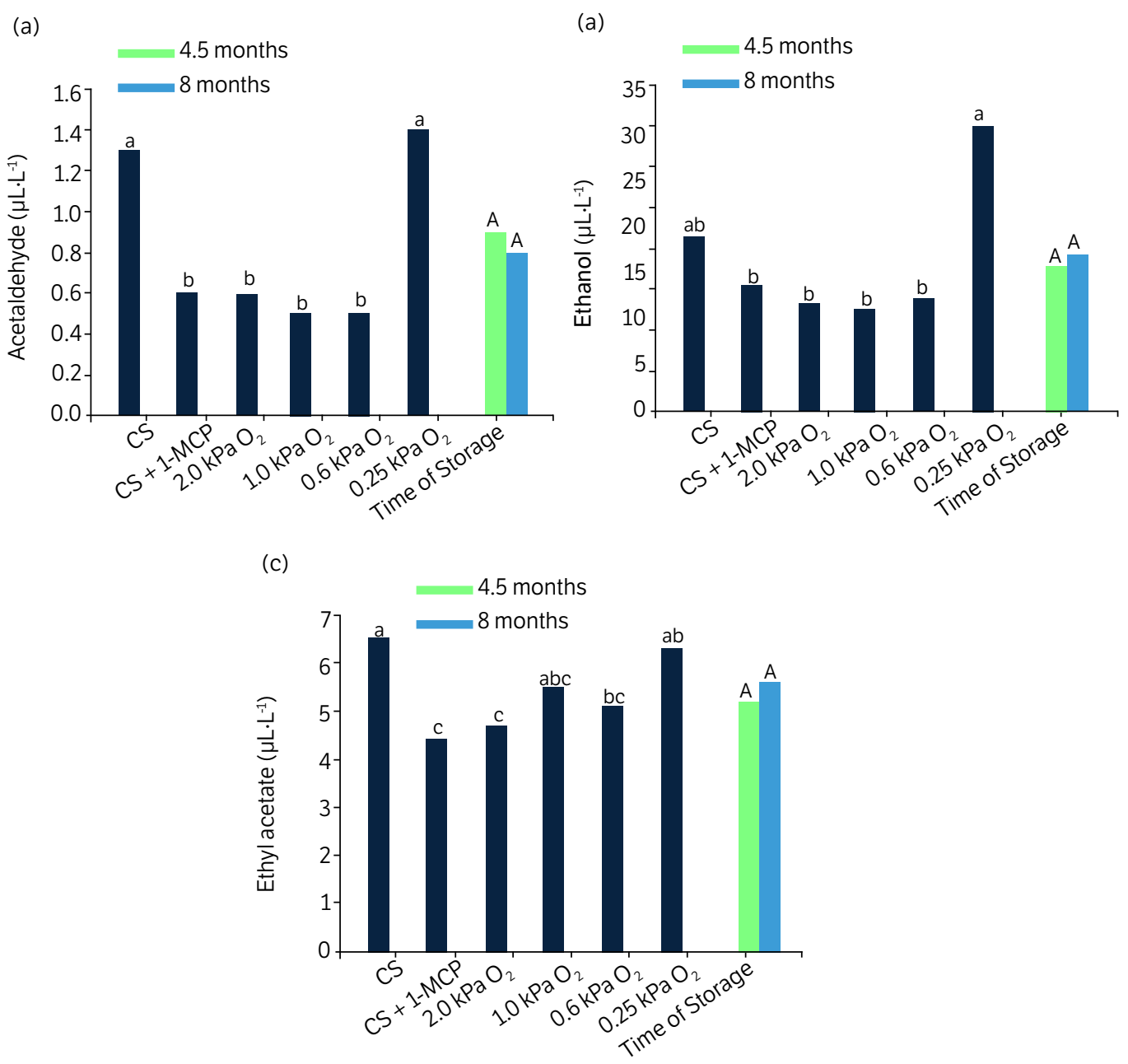

Figure 5. Production of acetaldehyde (a), ethanol (b), and ethyl acetate (c) in 'Cripps Pink' apples stored under different conditions, after 4.5 and 8 months of storage $\left(1.5 \pm 0.2^{\circ} \mathrm{C} / 92 \pm 2 \% \mathrm{RH}\right)$ plus 7 days of shelf life $\left(20 \pm 2{ }^{\circ} \mathrm{C} / 60 \pm 5 \% \mathrm{RH}\right)$.

Means followed by the same uppercase letter (time of storage) and same lowercase letter (storage conditions) in the bars do not differ by the LSD test at $5 \%$ of probability.

Although the 1-MCP provided TPC values in the peel similar to CA and superior to CS without 1-MCP, at 4.5 months of storage, in prolonged storage (8 months) it did not differ from CS without 1-MCP and was lower than CA conditions (Fig. 6). In the flesh, the CS + 1-MCP treatment did not differ from the CS without 1-MCP, in both storage periods. Ma et al. (2019) report that 1-MCP inhibited the action of ethylene and delayed fruit senescence, also inhibited the action of the phenylalanine ammonia lyase enzyme, thus reducing the production of phenolic compounds. According to Hoang et al. (2011), the application of 1-MCP can reduce some phenolic compounds in the peel and flesh of 'Cripps Pink' apples.

Regarding the TAA in the peel, the 1-MCP in both storage periods reduced the values concerning the CS without 1-MCP. Under CA conditions, at 4.5 months of storage plus 7 days of shelf life, only fruits stored in $2.00 \mathrm{kPa}_{2}$ of $\mathrm{O}_{2}$ showed higher TAA in the peel when compared to fruits under CS without 1-MCP (Figs. $6 \mathrm{c}$ and d). However, after 8 months of storage plus 7 days of shelf life, the fruits stored in $0.25 \mathrm{kPa}$ of $\mathrm{O}_{2}$ showed TAA in the peel superior to the fruits of the other 
treatments. After 4.5 months of storage plus 7 days of shelf life, the flesh of fruits stored under CA with $0.25 \mathrm{kPa}_{2}$ of $\mathrm{O}_{2}$ showed higher TAA values than the fruits under CS. After 8 months of storage plus 7 days of shelf life, fruits stored in all CA and CS + 1-MCP conditions showed higher TAA than fruits under CS without 1-MCP. Controlled atmosphere has a higher capacity to maintain the TAA of apples for a longer time when compared to CS (Łata 2008). Zucoloto et al. (2017) state that the effect of 1-MCP on the TAA of apples varies according to the cultivar and storage time. In Pink Lady apples, the TPC values is directly related to the TAA of the fruits (Zhao et al. 2019), which was also observed in this research.

(a)
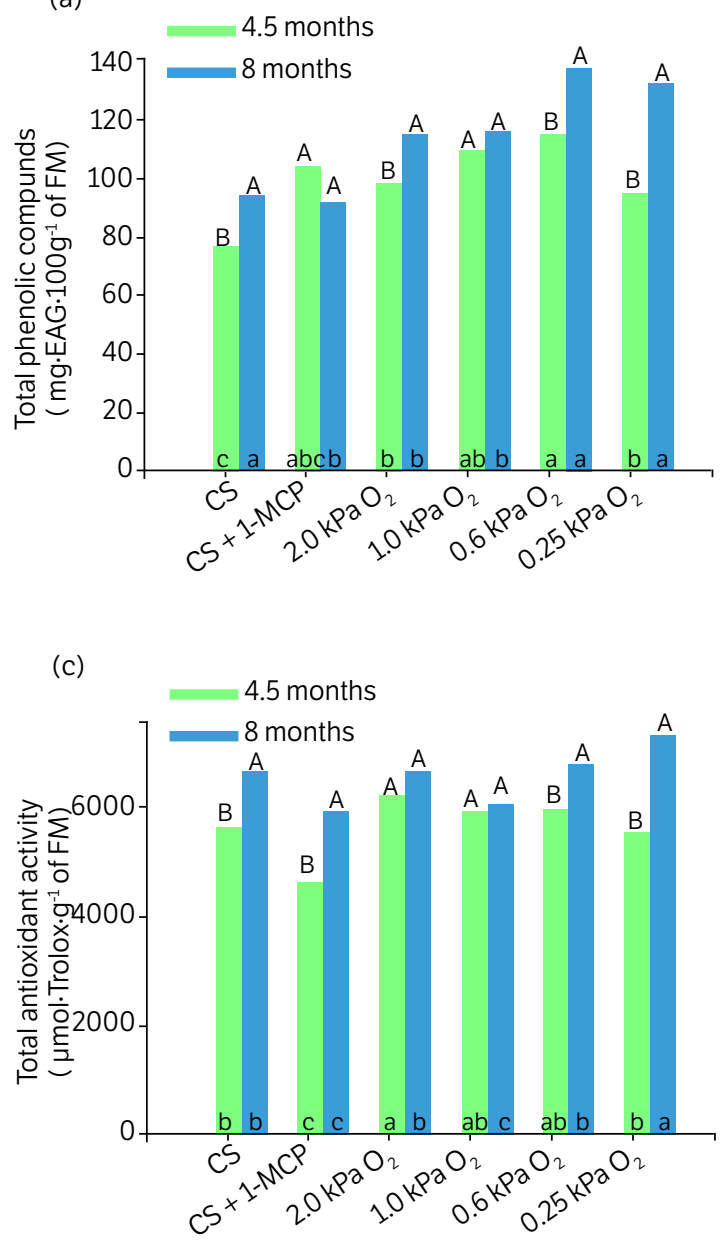

(b)

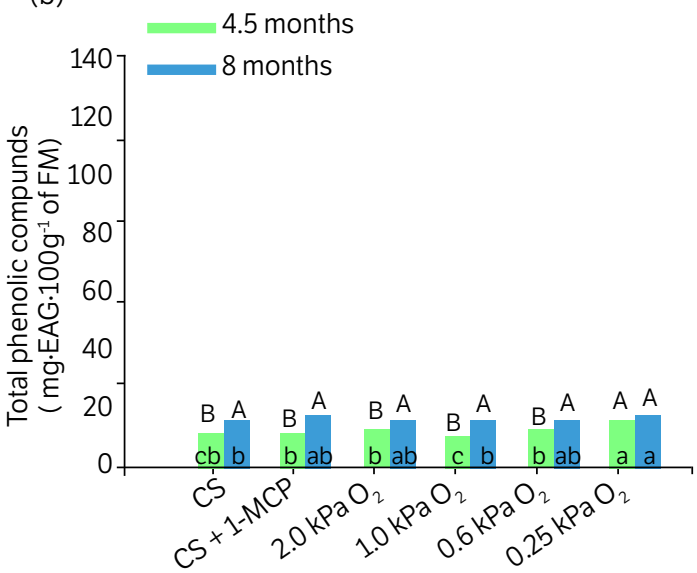

(d)

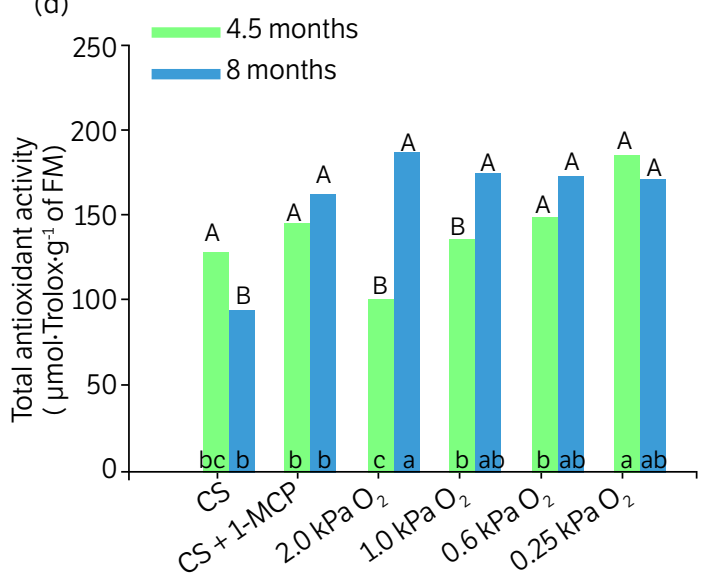

Figure 6. Content of total phenolic compounds (mg EAG $100 \cdot \mathrm{g}^{-1}$ of fresh mass) in the peel (a) and flesh (b) and total antioxidant activity ( $\mu \mathrm{mol} \cdot$ Trolox $\cdot \mathrm{g}^{-1}$ of fresh mass) in the peel (c) and flesh (d) of 'Cripps Pink' apples stored under different conditions, after 4.5 and 8 months of storage $\left(1.5 \pm 0.2^{\circ} \mathrm{C} / 92 \pm 2 \% \mathrm{RH}\right)$ plus 7 days of shelf life $\left(20 \pm 2^{\circ} \mathrm{C} / 60 \pm 5 \% \mathrm{RH}\right)$.

Means followed by the same uppercase letter (time of storage) and same lowercase letter (storage conditions) in the bars do not differ by the LSD test at $5 \%$ of probability.

\section{CONCLUSION}

The treatment with 1-MCP was effective in maintaining the quality of 'Cripps Pink' apples under CS just for 4.5 months. For longer storage (8 months), CA is more effective than CS combined or not with 1-MCP.

Storage under CA with $0.6 \mathrm{kPa}$ of $\mathrm{O}_{2}$ showed the best results for reducing the occurrence of superficial scald, decay, mealiness, and skin greasiness, without inducing high production of compounds resulting from the fermentative metabolism in 'Cripps Pink' apples. This storage also provided a higher content of total phenolic compounds and total antioxidant activity. 


\section{AUTHORS' CONTRIBUTION}

Conceptualization: Steffens C. A.; Methodology: Fernandes R. C., Steffens C. A., Anami J. M., Mosquera, D. J. C. and Amarante C. V. T; Investigation: Fernandes R. C., Steffens C. A., Anami J. M. and Mosquera, D. J. C.; Writing Original Draft: Fernandes R. C., Steffens CA., Anami J. M., Mosquera, D. J. C., Amarante C. V. T., and Brackmann A.; Writing - Review and Editing: Fernandes R. C., Steffens CA., Anami J. M., Mosquera, D. J. C., Brackmann A. and Amarante C. V. T.; Funding Acquisition: Steffens C. A. and Amarante C. V. T.; Resources: Steffens C. A. and Amarante C. V. T.; Supervision: Fernandes R. C.

\section{DATA AVAILABILITY STATEMENT}

All data sets were generated or analyzed in the current study.

\section{FUNDING}

Conselho Nacional de Desenvolvimento Científico e Tecnológico

[https://doi.org/10.13039/501100003593]

Grant No. 305069/2018-1

Coordenação de Aperfeiçoamento de Pessoal de Nível Superior

[https://doi.org/10.13039/501100002322]

Finance Code 001.

Fundação de Amparo à Pesquisa e Inovação do Estado de Santa Catarina

[https://doi.org/10.13039/501100005667]

Grant No. 2019TR950

\section{ACKNOWLEDGMENTS}

Not applicable.

\section{REFERENCES}

Anami, J. M., Steffens, C. A., Moreira, M. A., Fernandes, R. C., Mosquera, D. J. C. and Amarante, C. V. T. (2020). Active modified atmosphere storage to preserve the quality of 'San Andreas' strawberries harvest at two ripening stages. Revista Brasileira de Fruticultura, 42 , e-099. https://doi.org/10.1590/0100-29452020099

Baert, K., Devlieghere, F., Flyps, H., Oosterlinck, M., Ahmed, M. M., Rajković, A., Verlinden, B., Nicolaï, B., Debevere, J. and Meulenaer, B. (2007). Influence of storage conditions of apples on growth and patulin production by Penicillium expansum. International Journal of Food Microbiology, 119, 170-181. https://doi.org/10.1016/j.ijfoodmicro.2007.07.061

Bailey-Serres, J., Fukao, T., Gibbs, D. J., Holdsworth, M. J., Lee, S. C., Licausi, F., Perata, P., Voesenek, L. A. C. J. and van Dongen, J. T. (2012). Making sense of low oxygen sensing. Trends in Plant Science, 17, 129-138. https://doi.org/10.1016/j.tplants.2011.12.004 
Berghetti, M. R. P., Brackmann, A., Thewes, F. R., Schultz, E. E., Ludwig, V., Wendt, L. M., Thewes, F. R. and Schmidt, S. F. P. (2020). Extremely low oxygen partial pressures for the storage of 'Royal Gala' apple. Bragantia, 79, 145-154. https://doi.org/10.1590/1678-4499.20190016

Bodbodak, S. and Moshfeghifar, M. (2016). Advances in controlled atmosphere storage of fruits and vegetables. In M. W. Siddiqui. (Ed.), Eco-friendly technology for postharvest produce quality (p. 39-76). Cambridge: Academic Press. https://doi.org/10.1016/ B978-0-12-804313-4.00002-5

Boeckx, J., Hertog, M., Geeraerd, A. and Nicolai, B. (2019). Regulation of the fermentative metabolism in apple fruit exposed to lowoxygen stress reveals a high flexibility. Postharvest Biology and Technology, 149, 118-128. https://doi.org/10.1016/j.postharvbio.2018.11.017

Both, V., Thewes, F. R., Brackmann, A., Ferreira, D. F., Pavanello, E. P. and Wagner, R. (2016). Effect of low oxygen conditioning and ultralow oxygen storage on the volatile profile, ethylene production and respiration rate of 'Royal Gala' apples. Scientia Horticulturae, 209, 156164. https://doi.org/10.1016/j.scienta.2016.06.028

Brackmann, A., Guarienti, A. J. W., Saquet, A. A., Giehl, R. F. H. and Sestari, I. (2005). Condições de atmosfera controlada para a maçã 'Pink Lady'. Ciência Rural, 35, 504-509. https://doi.org/10.1590/S0103-84782005000300003

Brackmann, A., Weber, A., Pinto, J. A. V., Neuwald, D. A. and Steffens, C. A. (2008). Manutenção da qualidade pós-colheita de maçãs ‘Royal Gala’ e ‘Galaxy’ sob armazenamento em atmosfera controlada. Ciência Rural, 38, 2478-2484. https://doi.org/10.1590/ S0103-84782008000900010

Brizzolara, S., Santucci, C., Tenori, L., Hertog, M., Nicolai, B., Stürz, S., Zanella, A. and Tonutti, P. (2017). A metabolomics approach to elucidate apple fruit responses to static and dynamic controlled atmosphere storage. Postharvest Biology and Technology, $127,76-87$. https://doi.org/10.1016/j.postharvbio.2017.01.008

Cukrov, D., Zermiani, M., Brizzolara, S., Cestaro, A., Licausi, F., Luchinat, C., Santucci, C., Tenori, L., Van Veen, H., Zuccolo, A., Ruperti, B. and Tonutti, P. (2016). Extreme hypoxic conditions induce selective molecular responses and metabolic reset in detached apple fruit. Frontiers in Plant Science, 7, 146. https://doi.org/10.3389/fpls.2016.00146

Ding, R., Du, B. and Zhang, Y. (2019). Conjugated trienols and programmed cell death are more closely related to superficial scald than reactive oxygen species in apple fruit stored at low temperature. Scientia Horticulturae, 246, 597-603. https://doi.org/10.1016/j. scienta.2018.11.053

Floegel, A., Kim, D.-O, Chung, S.-J, Koo, S. I. and Chun, O. K. (2011). Comparison of ABTS/DPPH assays to measure antioxidant capacity in popular antioxidant-rich US foods. Journal of Food Composition and Analysis, 24,1043-1048. https://doi.org/10.1016/j.jfca.2011.01.008

Forney, C. F. (2016). Physiology and biochemistry of aroma and off-odors in fresh-cut products. Acta Horticulturae, 1141, 35-46. https:// doi.org/10.17660/ActaHortic.2016.1141.4

Gwanpua, S. G., Vicent, V., Verlinden, B. E., Hertog, M. L. A. T. M, Nicolai, B. M. and Geeraerd, A. H. (2014). Managing biological variation in skin background colour along the postharvest chain of 'Jonagold' apples. Postharvest Biology and Technology, 93, 61-71. https://doi. org/10.1016/j.postharvbio.2014.02.008

Hackbarth, C., Steffens, C. A., Amarante, C. V. T., Stanger, M. C. and Brackmann, A. (2017). Postharvest quality of 'Galaxy’ apples submitted to the treatment with 1-MCP and different cooling times between harvest and cold storage. Ciência Rural, 47, e20160926. https://doi. org/10.1590/0103-8478cr20160926

Hoang, N. T. T., Golding, J. B. and Wilkes, M. A. (2011). The effect of postharvest 1-MCP treatment and storage atmosphere on 'Cripps Pink' apple phenolics and antioxidant activity. Food Chemistry, 127, 1249-1256. https://doi.org/10.1016/j.foodchem.2011.01.052

Huan, C., Zhang, J., Jia, Y., Li, S., Jiang, T., Shen, S. and Zheng, X. (2020). Effect of 1-methylcyclopropene treatment on quality, volatile production and ethanol metabolism in kiwifruit during storage at room temperature. Scientia Horticulturae, 265, 109266. https://doi. org/10.1016/j.scienta.2020.109266 
Klein, B., Falk, R. B., Thewes, F. R., Anese, R. O., Santos, I. D., Ribeiro, S. R., Donadel, J. Z., Brackmann, A., Barin, J. S., Cichoski, A. J. and Wagner, R. (2020). Dynamic controlled atmosphere: Effects on the chemical composition of cuticular wax of 'Cripps Pink' apples after long-term storage. Postharvest Biology and Technology, 164, 111170. https://doi.org/10.1016/j.postharvbio.2020.111170

Łata, B. (2008). Apple peel antioxidant status in relation to genotype, storage type and time. Scientia Horticulturae, 117, 45-52. https:// doi.org/10.1016/j.scienta.2008.03.011

Ma, Y., Ban, Q., Shi, J., Dong, T., Jiang, C.-Z. and Wang, Q. (2019). 1-methylcyclopropene (1-MCP), storage time, and shelf life and temperature affect phenolic compounds and antioxidant activity of 'Jonagold' apple. Postharvest Biology and Technology, 150, 71-79. https://doi.org/10.1016/j.postharvbio.2018.12.015

Mazzurana, E. R., Argenta, L. C., Amarante, C. V. T. and Steffens, C. A. (2016). Potenciais benefícios do aumento da temperatura de armazenagem em atmosfera controlada de maçãs 'Gala' tratadas com 1-MCP. Revista Brasileira de Fruticultura, 38, 43-52. https://doi. $\operatorname{org} / 10.1590 / 0100-2945-237 / 14$

Mditshwa, A., Fawole, O. A., Vries, F., van der Merwe, K., Crouch, E. and Opara, U. L. (2017). Repeated application of dynamic controlled atmospheres reduced superficial scald incidence in 'Granny Smith' apples. Scientia Horticulturae, 220, 168-175. https://doi.org/10.1016/j. scienta.2017.04.003

Mditshwa, A., Fawole, O. A. and Opara, U. L. (2018). Recent developments on dynamic controlled atmosphere storage of apples: A review. Food Packaging and Shelf Life, 16, 59-68. https://doi.org/10.1016/j.fpsl.2018.01.011

Pedreschi, R. and Lurie, S. (2015). Advances and current challenges in understanding postharvest abiotic stresses in perishables. Postharvest Biology and Technology, 107, 77-89. https://doi.org/10.1016/j.postharvbio.2015.05.004

Saquet, A. A. and Streif, J. (2017). Respiration rate and ethylene metabolism of 'Jonagold' apple and 'Conference' pear under regular air and controlled atmosphere. Bragantia, 76, 335-344. https://doi.org/10.1590/1678-4499.189

Stanger, M. C., Steffens, C. A., Soethe, C., Moreira, M. A., Amarante, C. V. T., Both, V. and Brackmann, A. (2018). Phenolic compounds content and antioxidant activity of 'Galaxy' apples stored in dynamic controlled atmosphere and ultralow oxygen conditions. Postharvest Biology and Technology, 144, 70-76. https://doi.org/10.1016/j.postharvbio.2018.05.014

Thewes, F. R., Both, V., Brackmann, A., Weber, A. and Anese, R. O. (2015). Dynamic controlled atmosphere and ultralow oxygen storage on 'Gala' mutants quality maintenance. Food Chemistry, 188, 62-70. https://doi.org/10.1016/j.foodchem.2015.04.128

Thewes, F. R., Brackmann, A., Anese, R. O., Ludwig, V., Schultz, E. E. and Berghetti, M. R. P. (2018). 1-methylcyclopropene suppresses anaerobic metabolism in apples stored under dynamic controlled atmosphere monitored by respiratory quotient. Scientia Horticulturae, 227, 288-295. https://doi.org/10.1016/j.scienta.2017.09.028

Thewes, F. R., Thewes, F. R., Both, V., Schultz, E. E., Berghetti, M. R. P., Ludwig, V. and Brackmann, A. (2021). Static × dynamic controlled atmosphere: Impacts of aerobic and anaerobic metabolism on physiological disorders and overall quality of 'Royal Gala' apples. LWT, 141, 110922. https://doi.org/10.1016/j.Iwt.2021.110922

Watkins, C. B. (2006). The use of 1-methylcyclopropene (1-MCP) on fruits and vegetables. Biotechnology Advances, 24, 389-409. https:// doi.org/10.1016/j.biotechadv.2006.01.005

Weber, A., Brackmann, A., Anese, R. O., Both, V. and Pavanello, E. P. (2013). Atmosfera controlada para o armazenamento da maçã 'Maxi Gala'. Revista Ciência Agronômica, 44, 294-301. https://doi.org/10.1590/S1806-66902013000200011

Williamson, V. G., Frisina, C., Tareen, M. N. and Stefanelli, D. (2018). Storage performance of two ‘Pink Lady ${ }^{\circledR}$ clones differs, but 1-MCP treatment is beneficial, regardless of maturity at harvest. Scientia Horticulturae, 235, 142-151. https://doi.org/10.1016/j.scienta.2018.03.006 
Yang, Y., Zhou, B., Wang, C., Lv, Y., Liu, C., Zhu, X. and Ren, X. (2017a). Analysis of the inhibitory effect of 1-methylcyclopropene on skin greasiness in postharvest apples by revealing the changes of wax constituents and gene expression. Postharvest Biology and Technology, 134, 87-97. https://doi.org/10.1016/j.postharvbio.2017.08.013

Yang, Y., Zhou, B., Zhang, J., Wang, C., Liu, C., Zhu, X. and Ren, X. (2017b). Relationships between cuticular waxes and skin greasiness of apples during storage. Postharvest Biology and Technology, 131, 55-67. https://doi.org/10.1016/j.postharvbio.2017.05.006

Zhao, T., Sun, L., Wang, Z., Nisar, T., Gong, T., Li, D., Niu, P. and Guo, Y. (2019). The antioxidant property and -amylase inhibition activity of young apple polyphenols are related with apple varieties. LWT, 111, 252-259. https://doi.org/10.1016/j.Iwt.2019.05.006

Zucoloto, M., Ku, K.-M., Kim, M. J. and Kushad, M. M. (2017). Influence of 1-methylcyclopropene treatment on postharvest quality of four scab (Venturia inaequalis)-resistant apple cultivars. Journal of Food Quality, 2017, 5951041. https://doi.org/10.1155/2017/5951041 